\title{
GOAL ORIENTATION DAN SUBJECTIVE WELL BEING PADA LANSIA
}

\section{Dinie Ratri Desiningrum}

\author{
Fakultas Psikologi Universitas Diponegoro \\ J1. Prof Soedarto, SH, Tembalang, Semarang \\ dn.psiundip@gmail.com
}

\begin{abstract}
This study aimed to examine the relationship between goal orientation and subjective well-being in the elderly, which includes psychological well-being, emotional well-being and social well-being. The research subjects consisted of 90 elderly from the elderly group Adi Yuswo and Wulandaru Semarang obtained through simple random sampling. The data were obtained using a measuring instrument goal orientation (18 items, $\alpha=.87$ ), psychological well-being (33 items, $\alpha=.92$ ), social well-being (33 items, $\alpha=.93$ ), and emotional well-being (18 items, $\alpha=.95$ ). Measurements were made using Structural Equation Modelling (SEM) with Linear Structural Relations program (lisrel) 8.80. The analysis showed that the model of goal orientation influence on subjective well being appropriate to the research subject. Subject used their own goal orientation to acquire information, knowledge, insight and new experiences through the association that they follow (knowledge related goal) in addition to obtaining emotional well being. Goal orientation then significant influence to form an overall positive evaluation of the self (subjective well-being), particularly to emerge social acceptance and social actualization (social well being) in individuals aside form the psychological well being and emotional well being.
\end{abstract}

Keywords: goal orientation; subjective well being; psychological well being; social well being; emotional well being; elderly.

\begin{abstract}
Abstrak
Penelitian ini bertujuan untuk melihat hubungan antara goal orientation dan subjective well being pada lansia, yaitu mencakup psychological well being, emotional well being dan social well being. Subyek penelitian terdiri dari 90 lansia dari kelompok lansia Adi Yuswo dan Wulandaru Semarang yang diperoleh melalui simple random sampling. Data diperoleh menggunakan alat ukur goal orientation (18 aitem, $\alpha=0,87)$, psychological well being (33 aitem, $\alpha=0,92)$, social well being (33 aitem, $\alpha=0,93)$, dan emotional well being (18 aitem, $\alpha=0,95)$. Analisis data dilakukan dengan menggunakan Structural Equation Modelling (SEM) dengan program Linear Structural Relation (Lisrel) 8.80. Hasil analisis menunjukkan bahwa model pengaruh goal orientation terhadap subjective well being tepat untuk subyek penelitian. Goal orientation pada subyek mengarahkannya untuk memperoleh informasi, ilmu pengetahuan, wawasan dan pengalaman baru melalui perkumpulan yang mereka ikuti (knowledge related goal) selain untuk memperoleh emotional well being. Goal orientation kemudian berpengaruh secara signifikan untuk menumbuhkan suatu evaluasi keseluruhan yang positif terhadap diri (subjective well being) yaitu menumbuhkan penerimaan sosial dan aktualisasi sosial (social well being) pada individu selain membentuk psychological well being dan emotional well being.
\end{abstract}

Kata kunci: goal orientation; subjective well being; psychological well being; social well being; emotional well being; lansia

\section{PENDAHULUAN}

Menjadi tua adalah sesuatu yang pasti akan dialami semua orang di dunia ini jika berumur panjang. Sepanjang tahun 2000, populasi orang tua di dunia tumbuh lebih dari 795.000 setiap bulannya (Kinsella \& Velkoff, 2001), dan diperkirakan lebih dari dua kali lipatnya pada tahun 2025. Pada saat itu akan terdapat lebih dari 900 juta orang berusia di atas 60 tahun, dan dua pertiga mereka berada di negara berkembang termasuk Indonesia.

Dikatakan lagi bahwa dalam abad ke-20 terjadi dua perubahan besar pada daerahdaerah di dunia, terdapat orang-orang berpendidikan dan mengembangkan ilmu 
pengetahuan dan teknologi, yaitu harapan hidup meningkat hampir dua kali lipat, dan tingkat kesuburan turun secara dramatis. Akibatnya, populasi yang menua lebih banyak daripada kelahiran bayi. Ditemukan dalam satu jurnal, Growing old or Longevity, para ilmuwan menyebutkan bahwa tantangan masa depan adalah untuk membangun dunia yang responsif terhadap kebutuhan orang-orang tua (Carstensen, 2003).

Masa tua yang sukses sangat didambakan oleh setiap individu yang memasuki usia dewasa akhir. Kriteria sukses masih terus diperdebatkan oleh banyak ilmuwan perkembangan dan bidang lainnya. Teoriteori bermunculan dengan dasar pengertian tentang "sukses penuaan" yaitu suatu rangkaian perilaku ideal seiring keterbatasan di usia tua. Psikolog perkembangan menetapkan sukses di usia tua dengan adanya optimalisasi perkembangan usia dewasa akhir.

Patokan atas kesuksesan di usia dewasa akhir ini adalah kesiapan dalam memasuki usia lanjut (lansia), ditandai dengan penilaian sejahtera terhadap diri atau kesejahteraan diri (well-being) (Poulin \& Silver, 2007). Well being ini lebih dikenal dengan subjective well being. Banyak dilakukan studi subjective well being $\mathrm{di}$ berbagai negara industri barat yang menemukan bahwa sebagian besar orang menilai hidup mereka "di atas rata-rata" (Seligman, 2002). Di Amerika Serikat dideskripsikan bahwa usia dewasa madya dan dewasa akhir memiliki ciri khusus perihal kebahagiaan, $60 \%$ lansia memandang diri mereka sendiri sebagai "cukup bahagia" dan 25\% dewasa madya berkata bahwa mereka "cukup bahagia" (Ryff, 2004). Hal ini dikuatkan oleh hasil penelitian yang menemukan bahwa individu dewasa akhir (lansia) mengalami emosi negatif yang lebih rendah dibandingkan dengan individu yang lebih muda dalam suatu tugas antisipatif dan consummatory (Nielsen, Knutson \& Carstensen, 2009).
Laporan terkait dengan subjective well being pada lebih dari sejuta orang di 45 negara menunjukkan bahwa rata-rata penilaian pribadi secara global atas subjective well being adalah mengesankan yaitu 6,75 dalam skala 10 angka. Di Jakarta, Indonesia, ditemukan bahwa subjective well being cenderung rendah pada populasi dewasa awal, namun cenderung stabil bahkan meningkat pada populasi dewasa akhir (Ayuningsih, 2007).

Semakin sedikit jarak antara keinginan dan pencapaian maka semakin tinggi tingkat kebahagiaan. Meskipun jelas bahwa seseorang menjadi lebih bahagia ketika mereka dapat mencapai tujuan yang mereka anggap penting, hubungan antara tujuan dan kebahagiaan mencakup area yang lebih luas daripada sekedar mendapatkan apa yang kita inginkan. Ketika seseorang menerima dirinya sendiri dengan cara yang lebih positif, mereka akan tampil di hadapan orang lain dengan tingkat kepercayaan diri dan optimisme tertentu, yang nantinya akan membantu terciptanya reaksi positif dari orang lain dan hal itu akan meningkatkan kembali harga diri mereka. Penerimaan diri secara positif membentuk harga diri yang tinggi sehingga membangun relasi interpersonal yang baik individu dengan lingkungannya, kesejahteraan dipengaruhi oleh persepsi yang positif terhadap dukungan sosial yang diterima (Desiningrum, 2010).

Subjective well being adalah suatu kondisi sejahtera yang dirasakan individu berdasarkan aspek kognisi dan afeksi atau perasaannya sekaligus, atau terkait dengan apa yang dinamakan global well being, dinyatakan oleh Keyes \& Moe dalam Lopez \& Snyder (2003) terdiri dari psychological well being, social well being dan emotional well being.

Sebagai makhluk sosial, individu membutuhkan orang lain untuk berinteraksi, berbagi, dan saling menolong, termasuk para 
dewasa akhir. Dikaitkan dengan kesuksesan di usia dewasa akhir yaitu melalui subjective well being, maka relasi dengan orang lain dapat mempengaruhi pula. Relasi merupakan sebuah konteks ketika proses sosialisasi terjadi. Individu menggunakan ketrampilan meregulasi emosi dan kompetensi emosional melalui relasinya dengan orang-orang yang signifikan atau orang-orang yang penting baginya (Hartup, 2000).

Dilakukan penelitian longitudinal yang diperoleh dari Journal of Psychology and Aging (Carstensen, 2005) melalui wawancara terhadap 28 perempuan dan 22 laki-laki dari Child Guidance Study, dilakukan selama 34 tahun, kepada mereka diperiksa dan diberi nilai untuk frekuensi interaksi, kepuasan terhadap hubungan, dan derajat kedekatan emosional dalam 6 jenis hubungan. Hasilnya, frekuensi interaksi dengan kenalan dan teman dekat menurun sejak masa dewasa awal. Frekuensi interaksi dengan pasangan, keluarga dan saudara kandung meningkat pada masa dewasa akhir, dan kedekatan emosional meningkat sepanjang masa dewasa akhir ini dalam hubungan dengan kerabat dan teman dekat. Hasil temuan lainnya menunjukkan bahwa individu semakin dekat dengan mitra sosial sejalan dengan pertambahan usia.

Dari seluruh keterangan di atas dapat disimpulkan bahwa salah satu hal yang mempengaruhi subjective well being seseorang adalah bagaimana ia memaknakan situasi dalam jaringan sosialnya, yaitu berkaitan dengan aktivitas individu dalam pertemuan-pertemuan atau kegiatan organisasi, kualitas dan kuantitas aktivitas yang dilakukan dan dengan siapa kontak sosial dilakukan, dan keseluruhannya dapat memenuhi kebutuhan psikologis individu (Pinquart \& Sorenson, 2007). Bagaimana individu memaknakan suatu relasi sosioemosional untuk memenuhi kebutuhan psikologisnya dikenal dengan selektivitas sosioemosional (Carstensen, 1995).
Selektivitas sosioemosional berakar dari teori motivasi Maslow (Lang \& Carstensen, 2002) yang merupakan suatu dorongan dalam diri individu untuk secara selektif membentuk ukuran dan komposisi jaringan sosial, lalu memperoleh tujuan (Goal Orientation) dari jaringan sosial tersebut (Fredrickson \& Carstensen, 2001).

Goal Orientation dalam teori Selektivitas Sosioemosional, memiliki definisi yaitu kemampuan seseorang dalam menetapkan tujuan melalui jaringan sosial yang dipilihnya untuk pemenuhan kebutuhan diri individu (Carstensen, 2005). Teori Goal Orientation dari Laura Carstensen ini merupakan salah satu teori yang lahir dari psikologi positif perkembangan lansia yang kemudian dikembangkan ke usia dewasa awal dan madya. Maka hal ini berbeda dengan teori lain mengenai Goal Orientation seperti menurut Dweck dan rekan-rekan. Dweck menerangkan bahwa goal orientation yang dirumuskan berawal dari penelitian yang dilakukannya terhadap anak-anak sekolah dasar yang kemudian dikembangkan pada usia yang lebih tua. Goal Orientation menurut Dweck merupakan kemampuan individu dalam mengembangkan dan menguasai pengetahuan, keterampilan, dan keahlian, yang disebut sebagai orientasi belajar, dan kemampuan individu dalam menunjukkan dan memvalidasi kompetensi yang disebut sebagai orientasi kinerja (Dweck \& Elliott, 1983 dalam Yeo \& Neal, 2004).

Goal orientation dalam teori Selektivitas Sosioemosional, terdiri dari dua aspek: (1) knowledge-related goal, yaitu meliputi bagaimana perolehan pengetahuan, rencana karir, dan perkembangan dari hubungan sosial; (2) emotional-related goal, yaitu mencakup regulasi emosi, bagaimana menjalin interaksi emosional yang menyenangkan dengan mitra sosial. Di usia dewasa akhir umumnya seseorang lebih dominan memilih emotional related goal (Carstensen, Isaacowitz \& Charles, 2003). 
Usia dewasa akhir cenderung memelihara hubungan sosioemosional dengan jaringan sosial yang tidak terlalu luas, seperti dengan teman sejawat atau dalam satu rentang usia, misalnya dalam perkumpulan pensiunan, perkumpulan olahraga, arisan dan pertemuan rutin, dan perkumpulan haji (hasil survei Tanggal 10 Januari 2014).

Pada studi kasus mengenai lansia, banyak lansia yang pensiun kemudian sibuk membantu mengurus cucu dan rumah tangga anak, padahal kegiatan tersebut tidak mendayagunakan semua kelebihan dan potensi lansia. Lansia mempunyai kelebihan, yaitu memiliki banyak pengalaman kerja, kebijakan dan waktu yang lebih fleksibel. Lansia memiliki banyak waktu luang sehingga mempunyai lebih banyak waktu untuk mempelajari halhal yang belum diketahuinya. Pengetahuan yang baru akan membuat lansia dapat mengikuti perkembangan zaman sehingga dapat tetap mandiri di usia lanjut (Silvianingrum, 2012).

Berdasarkan hasil wawancara awal di lapangan 10 Februari 2014, pada beberapa lansia di perkumpulan lansia adi yuswo dan wulandaru Semarang, diperoleh keterangan bahwa terdapat perbedaan kegiatan yang dilakukan lansia setelah pensiun. Terdapat lansia yang enggan untuk bergaul dengan orang lain dan memilih untuk tinggal di rumah saja sehingga semakin lama ia semakin tidak bergaul yang selanjutnya akan membentuk keengganan untuk bersosialisasi. Terdapat pula lansia yang hanya menghabiskan waktunya dengan menonton televisi sehingga membuat lansia tersebut menjadi pasif yang akhirnya menjadi pelupa dan tidak mau bertemu dengan teman-teman sehingga kebutuhan sosial, intelektual, dan spiritual yang dimiliki akan menurun. Lansia yang tidak mau bersosialisasi akan berdampak pada diri mereka sendiri. Lansia merasa tidak bisa memberikan sesuatu sehingga ia merasa tidak dibutuhkan oleh orang-orang di sekitarnya. Kelompok lansia ini berkumpul dengan tujuan berbagi ilmu, pengalaman dan menjalani hobi bersama, seperti berolahraga bulutangkis, tenis, senam dan jalan sehat. Secara rutin para lansia juga melakukan kegiatan bersama seperti pengajian, arisan, menyanyi, dan rekreasi ke lokasi-lokasi dalam dan luar kota.

Relasi sosioemosional bagi dewasa akhir disebut sebagai hubungan yang dapat memberi kepuasan, dukungan dan memenuhi kebutuhan emosional. Setelah melakukan observasi terhadap perkumpulan lansia di Semarang ini, peneliti menilai terdapat keceriaan, kebahagiaan dan kesehatan secara umum (well-being) yang tampak dari kegiatan mereka yaitu olahraga di usia yang sudah tidak muda lagi yaitu 6074 tahun, dan kegiatan-kegiatan dalam pertemuan rutin. Wawancara awal dilakukan peneliti untuk melihat selektivitas sosioemosional khususnya goal oriented dari para pensiunan ini, yaitu cara subyek menetapkan tujuan melalui perkumpulan yang diikutinya bersama seluruh kegiatan di dalamnya, untuk memenuhi kebutuhan diri lansia, seperti memperoleh kenyamanan dan informasi serta pengalaman baru karena relasi dalam perkumpulan tersebut merupakan salah satu relasi sosioemosional yang dipilih ditinjau dari teori selektivitas sosioemosional.

Kesimpulan yang dapat diambil dari studi pendahuluan ini adalah, terdapat gambaran umum bahwa subyek dapat memperoleh tujuan sosial baik emotional related goal maupun knowledge related goal dari perkumpulan tersebut, dan hal ini berbeda dengan penelitian yang dilakukan di California (Lockenhoff \& Carstensen, 2008), juga penelitian di USA yang kemudian diulang di Hongkong, Taiwan dan China, yang menemukan kecenderungan dewasa akhir ini untuk memprioritaskan emotional related goal (Carstensen, Isaacowitz \& Charles, 2003).

Usia dewasa akhir lebih mengutamakan kepuasan emosi, sehingga mereka lebih 
memilih menghabiskan waktunya bersama orang-orang yang familiar dan memiliki relasi yang baik, sehingga seringkali malas berinteraksi di lingkungan yang baru (Carstensen, 2003), dan interaksi selektif ini dapat memaksimalkan pengalaman emosi yang positif dan meminimalkan resiko emosi negatif sejalan dengan bertambahnya usia individu. Dalam penelitian lintas budaya (Norwegia, Katolik, AfrikaAmerika, Cina-Amerika, Eropa-Amerika), ditemukan bahwa individu dewasa akhir lebih mampu mengontrol emosinya dan lebih sedikit mengalami pengalaman emosi negatif daripada usia yang lebih muda (Lawton \& Others, dalam Mroczek, 2001). Di Indonesia belum diadakan penelitian khusus mengenai selektivitas sosioemosional ini.

Dari latar belakang di atas, maka penelitian ini bertujuan untuk melihat hubungan antara goal orientation dan subjective well being, dan lebih jauh lagi adalah melihat hubungan goal orientation dengan psychological well being, social well being dan emotional well being, pada kelompok lansia Adi Yuswo dan Wulandaru Semarang.

Hipotesis pada penelitian ini, semakin tinggi goal orientation, baik itu mencakup aspek knowledge related goal maupun emotional related goal, maka semakin tinggi subjective well being. Dengan sub hipotesis, semakin tinggi goal orientation maka semakin tinggi pula psychological well being, social well being dan emotional well being pada lansia.

\section{METODE}

Penelitian ini menggunakan metode kuantitatif dengan desain korelasional.

Karakteristik sampel penelitian ini adalah:

1) Lansia berusia antara 60 - 74 tahun yang tergolong young old menurut Santrock (2006), yang sudah mengisi informed consent.
2) Sudah pensiun dari pekerjaannya, dan tidak bekerja lagi.

3) Sehat secara umum, dalam arti tidak memiliki penyakit kronis atau akut.

4) Berdomisili di Semarang dan sekitarnya, sebagai kontrol terhadap kemungkinan pengaruh perbedaan budaya atau lingkungan sosial.

Pengambilan sampel dilakukan secara simple random sampling dari 110 subjek yang tergabung dalam perkumpulan lansia wulandaru dan adi yuswo, Semarang dan diperoleh 90 subjek.

Berikut gambaran latar belakang subyek:

Tabel. 1. Karakteristik Subjek (N=90)

\begin{tabular}{l|lr}
\hline Jenis kelamin (P/L) & $37 / 53$ & \\
\hline Usia & $65-73$ & \\
\hline Domisili & $\begin{array}{l}\text { Jawa } \\
\text { (Semarang, }\end{array}$ & Tengah \\
& $\begin{array}{l}\text { Purwodari, } \\
\text { Kendal, }\end{array}$ & Pati, \\
& Solo, \\
& Banjarnegara) & \\
\hline $\begin{array}{l}\text { Pasangan } \\
\text { (Hidup/meninggal) }\end{array}$ & & \\
\hline Pekerjaan Terakhir & $\begin{array}{l}\text { Guru (17), Dosen (4) } \\
\text { Pengusaha (30), PNS } \\
\text { (9), TNI/Polisi (15), } \\
\end{array}$ & Ibu Rmh Tangga (15) \\
\hline
\end{tabular}

Pengumpulan data menggunakan self administered questionnaire. Dilakukan ujicoba dan pengambilan data, dengan bantuan software Statistical Packages for Social Science (SPSS) 21.0 for Windows dan Linear Structural Relation (Lisrel) 8.80, dilakukan pengujian model pengukuran dengan Metode Confirmatory Factor Analysis (CFA).

Variabel penelitian, terdiri dari:

1) Goal orientation, yaitu kemampuan seseorang dalam menetapkan tujuan melalui jaringan sosial yang dipilihnya untuk pemenuhan kebutuhan diri individu. Pengukuran variabel ini menggunakan skala psikologis yang 
berisi item-item pernyataan yang mengukur knowledge related goal dan emotional related goal (18 aitem, $\alpha=$ $0,87)$. Alat ukur ini diadopsi dari alat ukur Carstensen (1995). Goals Orientation Scale. Unpublished manuscript. Stanford University. Contoh item knowledge related goal: "Saya ingin memperluas wawasan dengan bergabung dalam perkumpulan ini”. Contoh item emotional related goal: "Menurut saya, teman-teman perhatian sama saya".

2) Subjective Well being adalah suatu pengukuran terhadap diri, mengenai perasaan sejahtera yang dinilai secara subjektif (Seligman, 2002). Terdapat beberapa aspek yang tercakup dalam alat ukur ini, yaitu:

a) Psychological well being, yang terdiri dari sub-aspek, yaitu self acceptance, personal growth, purpose in life, environmental mastery, autonomy, dan positive relation with others (33 aitem, $\alpha=0,92$ ).

Contoh item psychological well being untuk indikator self acceptance: "Saya merasa bangga melihat semua yang telah saya capai sejauh ini".

b) Social well being, yang terdiri dari 5 sub-aspek, yaitu social acceptance, social actualization, social contribution, social coherence, dan social integration (33 aitem, $\alpha=0,93$ ).

Contoh item unfavorable, social well being untuk indikator social acceptance: "Saya merasa orang-orang di sekitar saya tidak mempedulikan saya".

c) Emotional well being, yang terdiri dari 4 sub-aspek, yaitu affection; satisfaction in life, avowed happiness, dan life domain (18 aitem, $\alpha=0,95$ ).
Contoh item emotional well being untuk indikator life satisfaction: "Saya sangat puas dengan hidup saya".

Pengukuran dilakukan dengan menggunakan Structural Equation Modelling (SEM) dengan program Linear Structural Relation (Lisrel) 8.80. Kegunaan dari Lisrel adalah dapat dicari pengaruh antarvariabel sekaligus kontribusi dari setiap indikator terhadap variabel-variabelnya (Setyo, 2008).

Dalam penelitian ini, terdapat dua variabel yaitu goal orientation dan subjective well being, dimana pada variabel subjective well being dibentuk oleh tiga konstruk psikologis dari teoris yang berbeda untuk digabungkan ke dalam satu variabel besar, yaitu subjective well being (Keyes \& Moe dalam Lopez \& Snyder, 2003), sehingga jumlah item cukup banyak di masing-masing subvariabel/aspek yang kemudian diuji melalui model pengukuran confirmatory factor analysis (CFA) dengan tujuan mengestimasi muatan faktor yang secara teoritik diduga berhubungan dengan variabel latennya (Jöreskog \& Sörbom, 1996). Maka model penelitian ini secara umum terdiri dari empat konstruk psikologis (goal orientation, psychological well being, social well being dan emotional well being) sehingga menggunakan Structural Equation Model, untuk melihat pengaruh antar variabel.

Program Lisrel mengeluarkan suatu keluaran hasil kecocokan sebuah model struktural dan model pengukuran dengan data. Jöreskog \& Sörbom (1993) mengemukakan beberapa kriteria kecocokan antara model dengan data, dan dalam penelitian ini yang digunakan terutama adalah empat uji kecocokan yang biasa dilakukan yakni $\chi^{2}$, RMR, RMSEA, AGFI, CFI dan GFI (Hair, Black, Babin, Anderson \& Tatham, 2007). 


\section{HASIL DAN PEMBAHASAN}

\section{Hasil Pengujian Model}

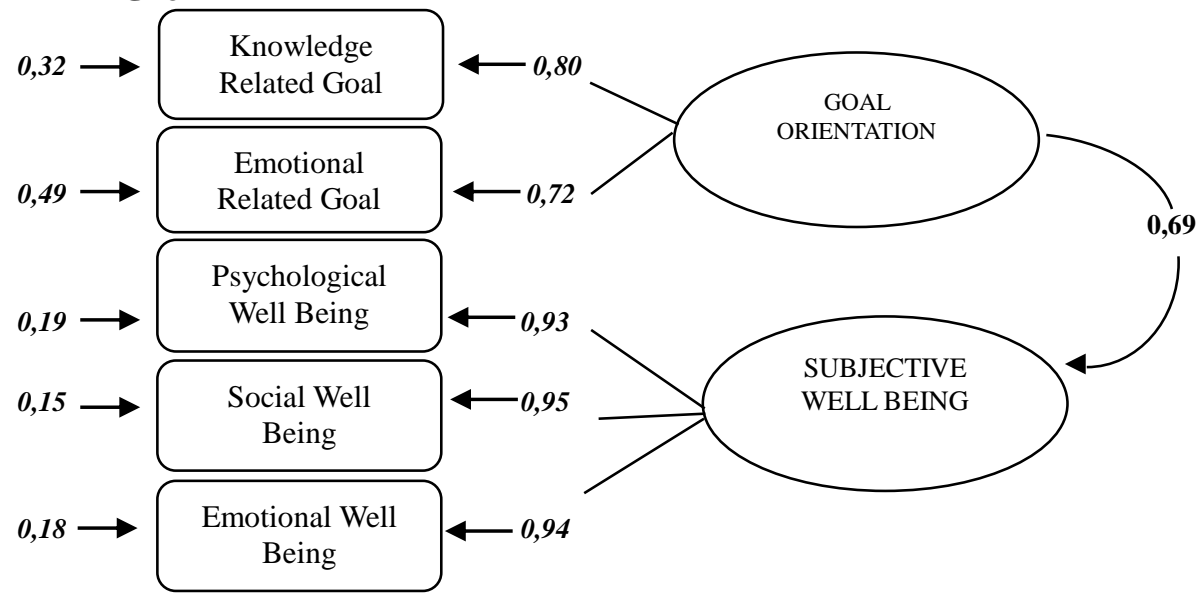

Chi Square $=10,11 ; \mathrm{df}=5 ; \mathrm{p}-$ value $=0,17 ;$ RMSEA $=0,08 ; \mathrm{CFI}=0,99 ; \mathrm{RMR}=0,02 ; \mathrm{GFI}=0,95 ;$ AGFI $=0,88$

Gambar 1. Model Pengaruh Goal Orientation terhadap Subjective Well Being

Tabel 2. Muatan Faktor \& Nilai Signifikansi Pengujian Model Pengaruh Goal Orientation terhadap Subjective Well Being

\begin{tabular}{llllc}
\hline \multicolumn{1}{c}{ Variabel } & \multicolumn{1}{c}{ Aspek } & $\begin{array}{c}\text { Muatan } \\
\text { Faktor }\end{array}$ & T & \multicolumn{1}{c}{ p } \\
\hline Goal Orientation & Knowledge $R G$ & 0,80 & 9,21 & $<0,001$ \\
& Emotional $R G$ & 0,72 & 8,11 & $<0,001$ \\
\hline Subjective Well Being & Psychological WB & 0,93 & 15,81 & $<0,001$ \\
& Social WB & 0,95 & 17,78 & $<0,001$ \\
& Emotional WB & 0,94 & 16,67 & $<0,001$ \\
\hline
\end{tabular}

Hasil pengujian model pada gambar 1 menunjukkan bahwa model cocok dengan data empirik dengan nilai chi-square $=10,11$; $\mathrm{df}=5$; dan $\mathrm{p}$-value $=0,17 ; \quad \mathrm{RMSEA}=0,08$; CFI $=0,99 ; \quad$ RMR $=0,02 ; \quad$ GFI $=0,95 ; \quad$ dan AGFI=0,88. Perolehan ini menyatakan bahwa Model Pengaruh Goal Orientation terhadap Subjective Well Being cocok dengan data penelitian (atau tergolong good fit).

Berdasarkan Tabel 2, terdapat gambaran muatan faktor dari aspek knowledge related goal dan emotional related goal pada variabel goal orientation, dan gambaran muatan faktor aspek social well being, emotional well being dan psychological well Tabel 3 menunjukkan hasil pengujian dari koefisien jalur atau pengaruh antar-variabel. Tampak bahwa goal orientation signifikan sangat berpengaruh terhadap subjective well being dengan besaran pengaruh sebesar 0,97. Dan sekaligus memiliki pengaruh yang juga cukup besar terhadap masing-masing aspek psychological well being, social well being dan emotional well being $(0,81,0,88$, dan 0,74$)$. Besaran perolehan pengaruh ini menunjukkan bahwa goal orientation sangat kuat mempengaruhi subjective well being namun sedikit lebih rendah pengaruh goal orientation terhadap psychological well being, social well being dan emotional well being being pada variabel subjective well being. 
Tabel 3. Koefisien Jalur \& Signifikansi pada Pengujian Model Pengaruh Goal Orientation terhadap Subjective Well Being

\begin{tabular}{|c|c|c|c|}
\hline Jalur & $\begin{array}{l}\text { Koefisien } \\
\text { Pengaruh }\end{array}$ & $t$ & $p$ \\
\hline $\begin{array}{l}\text { Goal } \\
\text { Orientation - } \\
\text { Subjective } \\
\text { Well Being }\end{array}$ & 0,97 & 0,44 & $<0,001$ \\
\hline $\begin{array}{l}\text { Goal } \\
\text { Orientation- } \\
\text { psychological } \\
\text { well being } \\
\text { Goal } \\
\text { Orientation- } \\
\text { social well } \\
\text { being } \\
\text { Goal } \\
\text { Orientation- } \\
\text { emotional } \\
\text { well being }\end{array}$ & $\begin{array}{l}0,81 \\
0,88 \\
0,74\end{array}$ & $\begin{array}{l}4,37 \\
3,49 \\
2,40\end{array}$ & $\begin{array}{l}<0,001 \\
<0,001 \\
<0,001\end{array}$ \\
\hline
\end{tabular}

Sukses di usia tua ditandai dengan penilaian sejahtera terhadap diri atau kesejahteraan diri (well-being) (Poulin \& Silver, 2007). Kesejahteraan diri ini lebih dikenal dengan subjective well being. Subjective well being meliputi psychological well being, social well being dan emotional well being. (Pratama, 2009).

Subjective well being individu salah satunya dipengaruhi oleh bagaimana mereka membangun komunitas sosial, dan memperoleh kepuasan dari komunitasnya tersebut yang menjadi bagian dari goal orientation. Goal orientation merupakan tujuan yang ditetapkan oleh individu dari hubungan sosioemosional yang dibentuk secara selektif (Carstensen, 2005).

Dari hasil penelitian ini, berdasarkan Tabel 2, untuk variabel goal orientation, tampak bahwa subyek memperoleh kedua tujuan sosial, yaitu emotional related goal dan knowledge related goal. Subyek memperoleh tujuan yang berkaitan dengan pengetahuan dan tujuan yang berkaitan dengan emosi melalui interaksi dengan lingkungannya.

Lansia yang mengikuti perkumpulan dengan berbagai aktivitasnya cenderung mendapatkan kedua tujuan sosial, yaitu selain tujuan yang berkaitan dengan ilmu pengetahuan (knowledge related goal) seperti untuk memperoleh informasi, ilmu pengetahuan dan wawasan baru serta menambah pengalaman-pengalaman baru, juga memperoleh tujuan terkait regulasi emosi, untuk menjalin interaksi emosional yang menyenangkan dengan mitra sosial (emotional-related goal).

Penelitian ini relevan dengan hasil penelitian lain yang menemukan bahwa pemenuhan kebutuhan psikologis sangat terkait dengan belajar, otonomi, merasa bermanfaat, rasa hormat, dan kemampuan untuk mengandalkan orang lain dalam keadaan darurat (Diener, Harter, \& Arora, 2010).

Hal ini berbeda dengan beberapa penelitian sebelumnya yang menemukan bahwa dewasa akhir memiliki kecenderungan lebih tinggi pada emotional related goal, yaitu tujuan sosial yang mencakup regulasi emosi, bagaimana menjalin interaksi emosional yang menyenangkan dengan mitra sosial, dan memperoleh makna emosional yang mendalam, dan kategori tujuan ini fokus pada "menyeimbangkan keadaan emosi atau mencari makna dari suatu hubungan" (Carstensen, Isaacowitz \& Charles, 2003).

Perbedaan ini bisa terjadi karena beberapa faktor, diantaranya berkaitan dengan karakteristik subyek penelitian seperti pada tabel 1, yaitu sebagian adalah lansia pensiunan pengajar, TNI/Polisi, pengusaha 
dan ibu rumah tangga, yang masih sehat dan aktif dalam pemikirannya, mengikuti kegiatan seminar dan menulis di surat kabar. Pensiunan memiliki aktivitas yang beragam, dan subyek tetap haus akan informasi, wawasan baru serta terus menambah pengalaman, dan beberapa dari mereka juga aktif menjadi narasumber di beberapa kegiatan. Di sisi lain, perkumpulan juga menumbuhkan perasaan nyaman, senang dan merasa dihargai, termasuk ketika para lansia bersenda gurau dan makan bersama. Suatu penelitian menyebutkan bahwa humor dapat memiliki dampak pada psikologi positif seseorang, diantaranya meningkatkan kekuatan karakter, kebijaksanaan, gaya berpikir, pengalaman dan tindakan (Radomska, 2012)

Untuk pengukuran variabel subjective well being, tampak melalui tabel 2 bahwa mayoritas subyek penelitian memiliki subjective well being yang positif, baik itu berupa psychological well-being, social well-being maupun emotional well-being.

Suatu studi menggunakan 553 sampel melihat pengalaman emosional individu dewasa awal. Lalu dipilih secara acak setiap hari untuk jangka waktu satu minggu. Pengambilan sampel satu minggu ini diulang lima dan sepuluh tahun kemudian. Maka analisis kurva cross-sectional menunjukkan bahwa penuaan terkait secara positif dengan emotional well being, dengan stabilitas dan kompleksitas emosional yang lebih besar. Temuan ini tetap kuat setelah memperhitungkan variabel lain yang mungkin terkait dengan pengalaman emosional (kepribadian, kefasihan lisan, kesehatan fisik, dan variabel demografis). (Carstensen, Turan, Scheibe, Ram, Ersner, Samanez, Brooks \& Nesselroade, 2011)

Berdasarkan Gambar 1, ditemukan hasil pengujian model yang menunjukkan bahwa model cocok dengan data empirik, nilai chi- square $=10,11 ; \quad \mathrm{df}=5 ; \quad$ dan $\quad \mathrm{p}$-value $=0,17$; RMSEA $=0,08 ; \quad \mathrm{RMR}=0,02 ; \quad \mathrm{CFI}=0,99$; GFI=0,95; dan AGFI=0,88. Hal ini berarti Model Pengaruh Goal Orientation terhadap Subjective Well Being cocok dengan data penelitian melalui kelompok dewasa akhir yang tergabung dalam perkumpulan. Kecocokan ini menunjukkan bahwa model tersebut benar-benar mengukur hubungan antara Goal Orientation dan Subjective Well Being. Didukung dengan data tabel 3, yang menunjukkan pengaruh yang tinggi goal orientation terhadap subjective well being.

Pada tabel 3, terdapat koefisien jalur yang menggambarkan hubungan antara goal orientation dengan subjective well being, maupun dengan psychological well being, social well being dan emotional well being. Tergambar bahwa pengaruh goal orientation lebih besar terhadap subjective well being $(0,97)$, dibandingkan ketiga aspek subjective well being. Hal ini berarti bahwa goal orientation memiliki pengaruh yang lebih tinggi terhadap ketiga konstruk psikologis ( $p$ sychological well being, social well being dan emotional well being) secara bersama-sama dalam subjective well being, daripada secara terpisah. Hal ini mempertegas teori Keyes \& Moe (dalam Lopez \& Snyder, 2003) yang menerangkan bahwa subjective well being merupakan ciri dari individu yang berfungsi secara penuh dalam hidupnya (full functioning) dan merupakan global well being, yang mencakup psychological well being, social well being dan emotional well being.

Suatu penelitian menggambarkan perbedaan yang signifikan dalam dinamika dua langkah kunci dari kesejahteraan subjektif, yaitu emosi dan evaluasi hidup. Ditemukan bahwa akhir pekan digunakan individu untuk evaluasi kehidupan, dengan diwarnai kondisi kebahagiaan, kesenangan, dan tawa daripada khawatir, sedih, dan marah (termasuk hari libur) dibandingkan 
hari kerja. Lebih lanjut ditemukan pentingnya konteks sosial, baik di kantor maupun di rumah, dalam menjelaskan ukuran dan kemungkinan faktor-faktor penentu efek akhir pekan yang mempengaruhi kondisi kesejahteraan seseorang. Artinya kondisi emosional, evaluasi diri dan sosial, membentuk subjective well being pada individu (Helliwell \& Shun, 2011).

Melalui pengukuran pengaruh goal orientation terhadap subjective well being, terdapat gambaran bahwa lansia yang memilih secara selektif jaringan sosialnya, dalam penelitian ini adalah perkumpulan lansia aktif, memiliki goal orientation yang tinggi, yaitu memperoleh dua tujuan yaitu memperluas wawasan serta mendapatkan kenyamanan emosional, sehingga di usianya yang sudah sampai pada dewasa akhir atau lansia, mampu terus sehat baik fisik maupun psikologis, tetap merasakan bermanfaat dan puas terhadap hidupnya, merasa diterima oleh lingkungan sosialnya, bahkan mampu mengaktualisasikan dirinya. Hal tersebut merupakan sebagian gambaran dari subjective well being lansia dalam penelitian ini. Atau dapat dikatakan tingginya goal orientation dari lansia, menumbuhkan subjective well being yang tinggi pula, dan hasil ini menjawab hipotesis penelitian.

Melalui hasil analisis model pengujian pengaruh ini, pada dasarnya ketiga aspek, yakni psychological well-being, social wellbeing dan emotional well-being, sama-sama berkontribusi dengan nilai muatan yang tidak jauh berbeda untuk membentuk subjective well being dewasa akhir yang tergabung sebagai partisipan penelitian, dan secara umum menunjukkan subjective well being yang tinggi, yaitu mereka menilai diri mereka sejahtera dengan bergabung dalam perkumpulan tersebut.
Uraian di atas didukung oleh suatu penelitian dengan sampel semi-bertingkat orang dewasa Norwegia yang menemukan bahwa subjek memahami kebahagiaan dan kehidupan yang baik sangat inklusif dengan domain kehidupan eksternal, sedangkan kepuasan diasosiasikan dengan keadaan internal khususnya psikologis dan pengalaman hidup. Kebahagiaan sehari-hari dan kehidupan baik yang terkait relasi sosial (social well being), lalu kepuasan yang terkait kondisi psikologis (psychological well being) merupakan konstruk psikologis yang tercakup di dalam konsep subjective well being (Carlquist, Ulleberg \& Fave, 2016).

Berdasarkan seluruh uraian di atas peneliti melihat bahwa goal orientation mempengaruhi keadaan subjective well being subjek penelitian. Secara umum ketika subjek memperoleh tujuan-tujuan sosial, yakni tujuan yang berkaitan dengan knowledge dan emotional, mereka memaknakan diri mereka termasuk pada orang-orang yang sejahtera, baik sejahtera secara psikologis, sosial maupun emosional.

Penelitian ini memiliki beberapa kelemahan, yaitu perumusan konsep goal orientation diperoleh dari teori tunggal, yaitu dari Carstensen (2005), karena peneliti menilai adanya perbedaan konsep dasar dari teori tersebut dengan teori goal orientation lainnya. Selain itu, subjective well being yang juga diambil dari satu konsep teori yaitu dari Keyes \& Moe (dalam Snyder \& Lopez, 2003) mengenai global well being sehingga mencakup tiga teori lainnya (psychological well being, social well being dan emotional well being), yang sedikit berbeda dari teori subjective well being dari Diener (Diener, Harter \& Arora, 2010). Kelemahan lainnya adalah, penelitian ini tidak secara jelas menerangkan intervening atau mediating variabel, sehingga dapat pula dianalisis dengan metode analisis berganda. 


\section{KESIMPULAN}

Berdasarkan hasil dan pembahasan, maka penelitian ini dapat disimpulkan bahwa mayoritas subyek penelitian memperoleh kedua tujuan sosial yang tinggi, yaitu emotional related goal dan knowledge related goal. Di samping itu, mayoritas subyek penelitian memiliki subjective well being yang tinggi pula.

Model Pengaruh Goal Orientation terhadap Subjective Well Being sesuai untuk subyek penelitian. Subjek memperoleh goal orientation yang tinggi yaitu berupa informasi, ilmu pengetahuan, wawasan dan pengalaman baru melalui perkumpulan yang mereka ikuti (knowledge related goal) dan juga kenyamanan dan dukungan emosional (emotional related goal). Goal orientation kemudian berpengaruh signifikan untuk menumbuhkan suatu evaluasi keseluruhan yang positif terhadap diri (Subjective Well Being) yang tinggi. Lebih lanjut, goal orientation yang tinggi menumbuhkan psychological well-being, social well-being dan emotional well-being yang tinggi pada individu.

\section{DAFTAR PUSTAKA}

Carlquist, E., Ulleberg, P., \& Fave, D. (2016). Everyday understandings of happiness, good life, and satisfaction: Three different facets of well-being. Applied Research in Quality of Life. 1-25. doi:10.1007/s11482-016-9472-9

Carstensen, L. L. (1995). Evidence for a life-span theory of socioemotional selectivity. Psychological Science, 4(5), 151-156.

Carstensen, L. L. (2003). Growing old or longevity. California: Stanford University.
Carstensen, L. L., Isaacowitz, D. and Charles, S.T .(2003). Taking time seriously: A theory of socioemotional selectivity. Journal of American Psychologist, 54, 165181.

Carstensen, L. L. (2005). Social and emotional patterns in adulthood: Support for socioemotional selectivity theory. Journal of Psychology and Aging, 7, 331-338.

Carstensen, L. L., Turan, B., Scheibe, S., Ram, N., Ersner-Hershfield, H., Samanez-Larkin, G. R., Brooks, K.P., \& Nesselroade, J. R. (2011). Emotional experience improves with age: Evidence based on over 10 years of experience sampling. Psychological Aging, 26(1), 21-33. doi: $10.1037 / \mathrm{a} 0021285$.

Desiningrum (2010). Family social support and psychological well being of elderly in Tembalang. Anima, Indonesian Psychological Journal. 26 (1), 61-68.

Diener, E., Harter, J., \& Arora, R. (2010). Wealth and happiness across the world: Material prosperity predicts life evaluation, whereas psychosocial prosperity predicts positive feeling. Journal Personality Social Psychology, 99(1), 52-61. doi: 10.1037/a0018066.

Fredrickson, B. L., \& Carstensen, L. L. (2001). Choosing social partners: How old age and anticipated endings make us more selective. Journal of Psychology and Aging, 5, 335-347.

Hair, J. F., Black, W. C., Babin, B. J., Anderson, R. F., \& Tatham, R. L. 
(2007). Multivariate data analysis: Sixth edition. London: Pearson International Edition.

Hartup, W. W. (2000). Social relationship and their developmental significance. American Psychologist, 44(2), 120 - 126.

Helliwell, J. F., \& Shun, W. (2011) Weekends and subjective wellbeing. PloS ONE, 10(12). doi: 10.1371/journal.pone.0145123.

Jöreskog, K., \& Sörbom, D. (1993). Lisrel 8: Structural equation modeling with the SIMPLIS command language. Chicago: Scientific Software International.

Jöreskog, K., \& Sörbom, D. (1996). Lisrel 8: User's reference guide. Chicago: Scientific Software International.

Kinsella, K., \& Velkoff, V. A. (2001). An aging world. Washington, DC: Economics and Statistics Administration.

Lang, F. R., \& Carstensen, L. L. (2002). Time counts: Future time perspective, goals, and social relationship. Psychology and Aging, 17(1), 125-139. doi:10.1037/08827974.17.1.125.

Lockenhoff, C. E., \& Carstensen, L. L (2008). Decision strategies in health care choice for self and others: Older but not younger adults make adjustment for the age of the decision target. Journal of Gerontology Series B, 63(2), 106109.

Lopez, S. J., \& Snyder, C. R. (2003). Positive psychological assessment: A handbook of models and measures. Washington, DC:

American Psychological Association (APA).

Mroczek, D. K. (2001). Age and emotion in adulthood. Current Directions in Psychological Science, 10, 87-90.

Ayuningsih, M. (2007). Kesejahteraan subjektif pada dewasa awal dan dewasa akhir. Tesis, Program Magister Psikologi, Universitas Indonesia.

Nielsen, L., Knutson, B., \& Carstensen, L. L. (2009). Affect dynamics, affective forecasting, and aging. Emotion, 9(5).

Pinquart, M., \& Sorensen, S. (2007). Correlates of physical health of informal caregivers: A metaanalysis. Journals of Gerontology, Series B Psychological Sciences and Social Sciences, 62(2), 126-137.

Poulin, M., \& Silver R. C. (2007). World benevolence beliefs and well-being across the life span. Psychology and Aging, 23(1).

Pratama, A. G. (2009). Kontribusi kesejahteraan subjektif pada religiusitas islam, persepsi tentang penyakit, dan perilaku menjaga kesehatan diri dalam model perilaku memelihara kesehatan, "Suatu upaya menemukan model perilaku memelihara kesehatan dengan taraf kecocokan optimal pada penderita HIV+". Disertasi (Tidak dipublikasikan). Program Pascasarjana, Universitas Padjadjaran Bandung.

Radomska, A. (2012). Humor from the perspective of positive psychology. Implications for research on 
development in adulthood. Polish Psychological Bulletin, 42(4), 215225. doi: 10.2478/v10059-0110028-4.

Ryff, C. D. (2004). In the eye of the beholder: Views of psychological well-being among middle and oldaged adults. Psychology and Aging, 4, 195-210.

Santrock, J. W. (2006). Life span development: Tenth edition. New York: McGraw-Hill Companies.

Seligman, M. E. P. (2002). Authentic happiness. Bandung: PT. Mizan Pustaka.
Setyo H, W. (2008). Structural equation modelling dengan lisrel 8.8: Konsep dan Tutorial. Yogyakarta: Graha Ilmu.

Silvianingrum, A. (2012). Manfaat belajar di usia lanjut. Skripsi. Fakultas Psikologi, Universitas Diponegoro Semarang.

Yeo, G., \& Neal, A. (2004). A multilevel analysis of effort, practice, and performance: Effects of ability, conscientiousness and goal orientation. Journal of Applied Psychology, 89, 231-247. 